\title{
PENGGUNAAN SOSIAL MEDIA WHATSAPP DAN PENGARUHNYA TERHADAP DISIPLIN BELAJAR PESERTA DIDIK PADA MATA PELAJARAN PENDIDIKAN AGAMA ISLAM \\ (Studi Kasus Di SMK Analis Kimia YKPI Bogor)
}

\author{
Edi Suryadi, M. Hidayat Ginanjar, M. Priyatna
}

(Guru SD Islam Terpadu Kreatifa Bogor), (Dosen Tetap Prodi MPI STAI Al Hidayah Bogor), (Dosen Tetap Prodi PAI STAI Al Hidayah Bogor)

Email: ginanjar@staialhidayahbogor.ac.id

Received: 06-03-18, Accepted: 01-04-18, Published: 16-04-18

\begin{abstract}
This study discusses the use of social media whatsapp and influence on the discipline learners learn on the subjects of Islamic Religious Education. This research was conducted at SMK Analyst Chemistry YKPI Bogor City. This study is based on the number of learners who use social media whatsapp in smartphones and always take them wherever they go including in the school environment. The purpose of this study to determine whether there is influence of whatsapp social media use to the discipline learners learn on the subjects of Islamic Religious Education. The approach used is quantitative with the method of experiment and survey, data collection techniques using questionnaires on the number of student population. Samples taken as many as 57 people with random sampling technique using Slovin formula. The unit of analysis is learners of Lessons 2016/2017. Analytical techniques used path analysis (descriptive and inferential statistical analysis). Based on the calculation, there is a correlation between the variables $X$ and $Y$ are marked positive with respect to the amount of $r X Y$ obtained that is equal to 0.921 at a significant level of $5 \%$ obtained rtabel value of 0.266 and at a significant level of $1 \%$ obtained value of 0.345 turns rxy the magnitude of 0.921 is much more higher than the rtabel of 0.266 and 0.345 . This shows a significant influence between variable $X$ to variable $Y$.
\end{abstract}

\begin{abstract}
Abstrak
Penelitian ini membahas tentang penggunaan sosial media whatsapp pengaruhnya terhadap disiplin belajar peserta didik pada mata pelajaran Pendidikan Agama Islam. Penelitian ini dilakukan di SMK Analis Kimia YKPI Kota Bogor. Kajian ini dilatar belakangi oleh banyaknya peserta didik yang menggunakan sosial media whatsapp dalam smartphone dan selalu membawanya kemanapun mereka pergi termasuk di lingkungan sekolah. Tujuan penelitian ini untuk mengetahui ada tidaknya pengaruh penggunaan sosial media whatsapp terhadap disiplin belajar peserta didik pada mata pelajaran Pendidikan Agama Islam. Pendekatan yang digunakan adalah kuantitatif dengan metode eksperimen dan survey, teknik pengumpulan data menggunakan angket pada jumlah populasi peserta didik. Sampel yang diambil sebanyak 57 orang dengan teknik random sampling menggunakan rumus Slovin. Unit analisis adalah peserta didik jadi Tahun Pelajaran 2016/2017. Teknik analisis yang digunakan berupa analisis jalur (path analysis), yaitu analisis statistik deskriptif dan inferensial. Berdasarkan perhitungan, terdapat korelasi
\end{abstract}


antara variabel $\mathrm{X}$ dan variabel $\mathrm{Y}$ bertanda positif dengan memperhatikan besarnya rXY yang diperoleh yaitu sebesar 0,921 pada taraf signifikan 5\% diperoleh nilai $r_{\text {tabel }}$ sebesar 0,266 dan pada taraf signifikan $1 \%$ diperoleh nilai sebesar 0,345 ternyata rxy yang besarnya 0,921 adalah jauh lebih tinggi daripada $r_{\text {tabel }}$ yang besarnya 0,266 dan 0,345. Ini menunjukkan adanya pengaruh yang signifikan antara variabel $\mathrm{X}$ terhadap variabel $\mathrm{Y}$.

Keywords: social media whatsapp, discipline learning.

\section{A. PENDAHULUAN}

Pendidikan dan komunikasi adalah dua bidang yang tidak dapat dipisahkan dari keluarga dan masyarakat. Sebagaimana dikatakan oleh Syahrini Tambak, bahwa pendidikan menekankan pada usaha yang penting untuk memelihara, mempertahankan, dan mengembangkan keberadaan masyarakat". ${ }^{1}$

Selanjutnya, perkembangan teknologi informasi dan komunikasi pada saat ini sudah berkembang sangat cepat sehingga tanpa disadari sudah sangat mempengaruhi setiap aspek kehidupan manusia dan yang paling populer dikalangan peserta didik adalah media sosial sebagai salah satu alat komunikasi.

Peran media sosial dalam dunia pendidikan sudah tidak terelakan lagi dan sudah menjadi bagian dalam pembelajaran baik di kalangan peserta didik sebagai media komunikasi ataupun atau hanya sebagai obrolan dengan sesama teman dan sumber belajar yang bisa didapat di luar kegiatan Belajar Mengar (KBM) di dalam kelas dan kita akan melihat bagaimana penggunaan media sosial secara umum.
Akses terhadap media telah menjadi salah satu kebutuhan primer pada setiap orang. Itu dikarenakan adanya kebutuhan akan informasi, hiburan, pendidikan, dan akses pengetahuan dari belahan bumi yang berbeda, kemajuan teknologi dan informasi serta semakin canggihnya perangkat-perangkat yang diproduksi oleh industri teknologi informasi seperti menghadirkan "dunia dalam genggaman".

Menurut data terbaru dari We Are Social, pengguna internet aktif di seluruh dunia kini mencapai angka 3,17 miliar. Dari tahun ke tahun, jumlah pengguna internet bertumbuh hingga 7,6\% . Pertumbuhan penggunaan internet ini juga berpengaruh terhadap pertumbuhan pengguna media sosial dan mobile. Menurut laporan yang sama, pengguna media sosial aktif kini mencapai 2,2 miliar, sedangkan pengguna mobile mencapai 3,7 miliar. Menariknya, pertumbuhan yang paling signifikan ditunjukkan oleh pengguna yang mengakses media sosial melalui platform mobile. Pengguna jenis ini bertumbuh hingga 23,3\%. Sementara itu, facebook masih menjadi media sosial

1 Syahrini Tambak. 2013. Pendidikan Komunikasi Islam. Jakarta: Kalam Mulia. hlm. 59. 
yang paling banyak digunakan dengan angka mencapai hampir 1,5 miliar. ${ }^{2}$

Ada banyak jenis-jenis media sosial yang perlu diketahui, banyak sumber terutama liputan media maupun kajian literatur, yang membagi jenis media sosial. Di antaranya yaitu; media jejaring sosial (social networking), jurnal online (blog), jurnal online sederhana atau termasuk konsekuensi atau efek hubungan sosial tersebut, di dunia virtual. Hal ini seperti dikatakan oleh Rulli Nasrullah, bahwa situs jejaringan media sosial yang paling populer, media sosial tersebut memungkinkan anggota untuk berinteraksi satu sama lain. Interaksi bukan hanya pada teks, tapi juga termasuk foto dan video yang mungkin menarik perhatian orang lain semua pfosting (publikasi) merupakan real time, memungkinkan anggota untuk berbagi informasi seperti apa yang sedang terjadi. ${ }^{3}$

Keberadaan media sosial itu memang menuntut masyarakat tidak terkecuali para peserta didik untuk mengikuti trend perkembangan jaman khususnya di bidang komunikasi. Tetapi apabila perkembangan teknologi tidak digunakan sebagaimana mestinya, dengan kata lain hanya sebatas trend dan digunakan untuk hal-hal yang tidak baik, tentunya akan berdampak pada tindakantindakan asusila. Bahkan keberadaan teknologi ini juga bisa membuat orang kecanduan dan asyik berada dalam kehidupan dunia maya.

2 https://id.techinasia.com/talk/statistikpengguna-internet-dan-media-sosial-terbaru/, diakses tanggal 16 Maret 2017 pukul 23.05 WIB.

3 Rulli Nasrullah. 2015. Media Sosial. Bandung: Sembiosa Rekatama Media. hlm. 40.
Berdasarkan survey pendahuluan yang dilakukan peneliti di Sekolah Menengah Kejurusan (SMK) Analis Kimia YKPI Bogor pada bulan April 2016, peneliti mengidentifikasi tingkat kedisiplinan belajar peserta didiknya masih rendah. Berdasarkan informasi yang didapatkan bahwa hasil studi yang dicapai peserta didik masih tergolong rendah, misalnya; nilai ulangan harian dan juga tingkat kedisiplinan siswa berdasarkan penilaian dari guru BK masih rendah, ada juga beberapa peserta didik yang tidak mentaati tata tertib, dan tidak mengerjakan tugas, mereka belajar dengan sungguh-sungguh ketika akan menghadapi tes atau ujian. Hal itu tentu saja berdampak pada capaian prestasi akademik yang kurang memuaskan atau tidak dapat mencapai hasil belajar yang diharapkan. Berdasarkan observasi dan wawancara di lapangan, ada beberapa peserta didik kurang disiplin dalam mengerjakan tugas di rumah yang diberikan dan tidak memperhatikan serta tidak mencatat materi pelajaran yang diberikan sehingga dianggap masih kurang mendukung terhadap pencapaian prestasi belajar peserta didik. Padahal bisa saja faktor motivasi dan tingkat kedisiplinan yang terdapat pada diri peserta didik menjadi salah satu faktor utama untuk pencapaian prestasi belajar yang baik. Tetapi pada kenyataannya faktor dari dalam diri saja tidak sepenuhnya menunjang dalam proses meraih prestasi belajar tanpa adanya dukungan dari guru sebagai pembimbing dalam proses belajar mengajar. Sementara itu, dari pengamatan, bahwa salah satu yang menjadi penyebab rendahnya kedisiplinan peserta didik 
adalah kebiasaannya dalam menggunakan media sosial di antaranya media sosial Whatsapp.

Berdasarkan observasi yang dilakukan peneliti bahwa nilai rata-rata prestasi belajar peserta didik SMK Analis Kimia YKPI Bogor semester satu pada mata pelajaran Pendidikan Agama Islam secara umum terdapat masalah terutama dalam hal kedisiplinan belajar. Hal ini dimungkinkan karena pengaruh dari penggunaan media sosial Wathshap sehingga dapat mempengaruhi prestasi belajar dan rendahnya kedisiplinan belajar peserta didik.

Berdasarkan uraian di atas, maka peneliti sangat tertarik melakukan penelitian lebih mendalam mengenai penggunaan media sosial Wathshap dan pengaruhnya terhadap kedisiplinan belajar peserta didik pada mata pelajaran Pendidikan agama Islam, studi kasus pada peserta didik di SMK Analis Kimia YKPI Bogor.

Di lihat dari sisi substansi dan batasan masalahnya, maka masalah penelitian ini dapat dirumuskan yaitu, "Adakah pengaruh penggunaan media sosial Whatsapp terhadap disiplin belajar peserta didik pada mata pelajaran Pendidikan Agama Islam?

Menurut Sukardi, beberapa ciri penelitian yang memiliki dasar positivisme, antara lain; 1) Menekankan objektivitas secara universal dan tidak dipengaruhi oleh ruang dan waktu, 2) Menginterpretasi variabel yang ada melalui peraturan kuantitas atau angka, 3) Memisahkan antara peneliti dengan objek yang hendak diteliti, dan 4) Menekankan penggunaan metode statistik untuk mencari jawaban permasalahan yang hendak diteliti. ${ }^{4}$

Adapun tujuan dalam penelitian ini adalah untuk mengetahui pengaruh penggunaan media sosial whatsapp terhadap disiplin belajar peserta didik pada mata pelajaran Pendidikan Agama Islam di SMK Analis Kimia YKPI Bogor.

Hasil dari penelitian ini diharapkan memiliki kegunaan atau manfaat bagi para pemerhati pendidikan maupun akademisi, baik secara teoritis maupun manfaat secara praktis. Dari aspek teoritis, penelitian ini diharapkan dapat memberi manfaat bagi pengembangan ilmu pengetahuan terutama yang terkait dengan permasalahan perilaku sosial yang terkait dengan pengembangan ilmu pendidikan sesuai dinamika zaman khususnya dalam pengelolaan lembaga pendidikan formal sebagai instrumen penting dalam mewujudkan pendidikan yang berkualitas dan berintegritas, baik aspek intelektual, emosional maupun dimensi spiritual. Sedangkan dari aspek praktis, penelitian ini diharapkan dapat menjadi bahan pertimbangan dalam menetapkan kebijakan-kebijakan dan pengembangan penyelenggaraan program pendidikan jangka panjang oleh para pengelola lembaga pendidikan pada umumnya dan terutama oleh lembaga yang diteliti untuk mendapatkan masukan-masukan atau rekomendasi dalam meningkatkan kualitas penyelenggaraan pendidikan dasar dan menengah yang terkait pengembangan dan metodologi pembelajaran agama

4 Sukardi. 2008. Metodologi Penelitian Pendidikan Kompetensi dan Praktiknya. Jakarta: Bumi Aksara. hlm. 83. 
Islam. Di samping itu, hasil penelitian ini juga diharapkan menjadi pemacu sekaligus pendorong bagi peneliti sejenis, sehingga terbuka peluang bagi penemuan teori baru berkaitan dengan permasalahan pendidikan agama Islam.

\section{B. TINJAUAN PUSTAKA}

\section{Media Sosial WhatsApp (WA)}

Media sosial WhatsApp yang sering disingkat WA adalah salah satu media komunikasi yang dapat di install dalam Smartphone. Media sosial ini digunakan sebagai sarana komunikasi chat dengan saling mengirim pesan teks, gambar, video bahkan telpon. Media ini dapat aktif jika kartu telpon pengguna memiliki paket data internet.

Penjelasan lebih ditail mengenai WatsApp sebagaimana dikatakan oleh Hartanto, bahwa WhatsApp adalah aplikasi pesan untuk smartphone dengan basik mirip Black Berry Messenger. WhatsApp Messenger merupakan aplikasi pesan lintas platform yang memungkinkan orang dapat bertukar pesan tanpa biaya SMS, karena WhatsApp Messenger menggunakan paket data internet yang sama untuk email, browsing web, dan lain-lain. Aplikasi WhatsApp Messenger menggunakan koneksi $3 \mathrm{G} / 4 \mathrm{G}$ atau $\mathrm{WiFi}$ untuk komunikasi data. Dengan menggunakan WhatsApp, kita dapat melakukan obrolan online, berbagi file, bertukar foto, dan lain-lain. ${ }^{5}$

Sementara itu, sumber lain menerangkan bahwa WhatsApp adalah

5 Aat Hartanto. 2010. Panduan Aplikasi Smartphone. Jakarta: Gramedia Pustaka Utama. hlm. 100 . aplikasi pesan instan untuk smartphone. Jika dilihat dari fungsinya WhatsApp hampir sama dengan aplikasi SMS yang biasa dipergunakan di ponsel lama. Tetapi WhatsApp tidak menggunakan pulsa, melainkan data internet. Jadi, di aplikasi ini seseorang tak perlu khawatir soal panjang pendeknya karakter. Tidak ada batasan, selama data internet memadai. Meskipun merupakan aplikasi pesan instan, ada yang unik dari WhatsApp. Jadi, sistem pengenalan kontak, verifikasi dan pengiriman pesan tetap dilakukan melalui nomor ponsel yang sudah terlebih dahulu didaftarkan. Cara ini berbeda dengan BBM yang menggunakan PIN, ataupun LINE yang selain nomor ponsel juga mendukung email, dan nama pengguna. ${ }^{6}$

Berdasarkan keterangan di atas, dapat disimpulkan bahwa WhatsApp adalah aplikasi pesan untuk smartphone dengan basic mirip BlackBerry Messenger. WhatsApp Messenger itu sendiri merupakan aplikasi pesan lintas platform yang memungkinkan seseorang bertukar informasi tanpa biaya SMS, karena WhatsApp Messenger menggunakan paket data internet yang sama untuk email, browsing web, dan lain-lain. Aplikasi WhatsApp Messenger biasanya menggunakan koneksi 3G/4G atau WiFi untuk komunikasi data. Dengan menggunakan WhatsApp, seseorang dapat melakukan obrolan online, berbagi file, dan bertukar informasi.

WhatsApp secara resmi telah mengumumkan peluncuran fitur

6 https://dailysocial.id/post/apa-itu-whatsapp, diakses tanggal 20 April 2017 pukul 21.50 WIB. 
resminya bernama Whatsapp Web pada tanggal 22 Januari 2015. Fitur ini mencoba memfasilitasi penggunaan aplikasi ini untuk pengguna berbasis komputer. Layaknya WhatsApp berbasis telepon genggam, fitur ini membutuhkan koneksi internet sebagai jalur penyampaikan informasi. WhatsApp bekerja melalui portal online yang disediakan oleh pengembang yang beralamat di situs www.web.whatsapp.com. WhatsAppweb pada prinsipnya berfungsi untuk membuka akun WhatsApp melalui perangkat komputer. Fitur ini pada periode awal lebih mudah digunakan melalui aplikasi Chrome yang dikembangkan oleh Google. Sinkronisasi dibutuhkan untuk membuka akun WhatsApp melalui website. Pengembang menyediakan barcode yang perlu dipindai melalui aplikasi WhatsApp mobile. Pemindaian akan secara langsung membuka aplikasi Whatsapp sesuai dengan akun yang berfungsi pada telepon genggam yang digunakan untuk pemindaian. Percakapan yang terdapat pada aplikasi WhatsApp di telepon seluler akan turut disajikan pada versi web tersebut. Sinkronisasi akan dilakukan secara otomatis apabila terjadi perubahan pada salah satu aplikasi yang aktif. $^{7}$

Keberadaan media sosial WhatsApp merupakan salah satu bukti perkembangan teknologi dan komunikasi yang harus disikapi dengan positif. Beberapa keuntungan memakai media sosial WhatsApp, antara lain; Pertama,
WhatsApp memiliki fitur untuk mengirim gambar, video, suara, dan lokasi GPS via hardware GPS atau Gmaps. Media tersebut langsung dapat ditampilkan dan bukan berupa link. Kedua, terintegrasi ke dalam sistem WhatsApp, layaknya sms, tidak perlu membuka aplikasi untuk menerima sebuah pesan. Notifikasi pesan masuk ketika handphone sedang off akan tetap disampaikan jika handphone sudah on. Ketiga, status Pesan; jam merah untuk proses loading pada Handphone terdapat tanda centang $(\sqrt{ })$ jika pesan terkirim ke jaringan, kemudian muncul tanda centang ganda $(\sqrt{ } \sqrt{ })$ jika pesan sudah terkirim ke teman chat. Adapun tanda silang merah jika pesan yang dikirimkan gagal. Keempat, Broadcats dan Groupchat; Broadcast untuk kirim pesan ke banyak pengguna. Group chat untuk mengirim pesan ke anggota sesama komunitas. Kelima, hemat Bandwidth, Karena terintegrasi dengan sistem, maka tidak perlu login dan loadingcontact/ avatar, sehingga transaksi data makin irit. Aplikasi dapat dimatikan, dan hanya aktif jika ada pesan masuk sehingga bisa menghemat baterei. ${ }^{8}$

Memang pengaruh dari kemajuan teknologi informasi dan komunikasi terhadap dunia pendidikan khususnya dalam proses pembelajaran mampu meningkatkan kualitas mutu pendidikan itu sendiri. Sebagaimana dikemukakan Rosenberg, bahwa dengan berkembangnya penggunaan teknologi informasi dan komunikasi ada lima pergeseran di dalam proses pembelajaran http://www.whatsapp.com, diakses tanggal 20 April 2017 pukul 22.15 WIB. http://www.whatsapp.com, diakses tanggal 20 April 2017 pukul 22.15 WIB. 
yaitu; 1) pergeseran dari penelitian ke penampilan, 2) pergeseran dari ruang kelas ke di mana dan kapan saja, 3) pergeseran dari kertas ke "on line" atau saluran, 4) pergeseran fasilitas fisik ke fasilitas jaringan kerja, dan 5) pergeseran dari waktu siklus ke waktu nyata. ${ }^{9}$

Berdasarkan uraian di atas bahwa dapat diambil hikmahnya bahwa penggunaan media sosial WhatsApp memberi manfaat secara positif bagi penggunanya, diantaranya yaitu; untuk mempermudah berkomunikasi, media sosial WhatsApp adalah media komunikasi, baik jarak dekat maupun jarak jauh dan merupakan alat komunikasi lisan atau tulisan yang dapat menyimpan pesan dan sangat praktis untuk dipergunakan sebagai media komunikasi yang terinstal dalam smartphone karena bisa dibawa kemana saja. Sebab itulah media sosial WhatsApp sangat berguna untuk alat komunikasi jarak jauh yang semakin efektif dan efisien. Untuk meningkatkan jalinan sosial, di samping sebagai media komunikasi, dapat berfungsi untuk meningkatkan jalinan sosial karena dengan media sosial WhatsApps seseorang bisa tetap berkomunikasi dengan saudara yang berada jauh, agar selalu menjaga tali silaturahim dan kerap kali juga digunakan untuk menambah teman. Untuk menambah pengetahuan tentang kemajuan teknologi, karena media komunikasi media sosial WhatsApp merupakan salah satu buah hasil dari kemajuan teknologi saat ini,

9 Rosenberg Marc. J. E-Learning. 2001. Strategies for Delivering Knowledge in The Digital Age. USA: McGraw-Hill Companies. hlm. 1. maka Media sosial WhatsApp tersebut dapat dijadikan salah satu sarana untuk menambah pengetahuar peserta didik tentang kemajuan teknologi sehingga peserta didik tidak dikatakan menutup mata akan kemajuan di era globalisasi saat ini, jika kita amati saat ini feature media sosial WhatsApp sangatlah lengkap. Selain itu, manfaat media sosial bisa pula sebagai alat penghilang stress. Seperti yang telah diungkapkan sebelumnya bahwa media sosial WhatsApp saat ini sudah memiliki feature yang sangat lengkap, sehingga feature tersebut dapat dijadikan seseorang untuk menghilangkan stress. Mungkin masih banyak lagi manfaat yang dapat diambil dari kemajuan alat teknologi komunikasi media sosial WhatsApp saat ini, tapi penulis berasumsi bahwa manfaat media sosial WhatsApp di atas dapat diperoleh apabila media sosial WhatsApp tersebut dapat digunakan dengan bijaksana sesuai dengan urgensitas kebutuhan dan fungsi yang sewajarnya.

\section{Disiplin Belajar}

Secara etimologis, istilah disiplin berasal dari bahasa latin "disciplina" yang menunjuk pada kegiatan belajar dan mengajar. Dalam bahasa Inggris "discipline" yang berarti: tertib, taat, atau mengendalikan tingkah laku, penguasaan diri, kendali diri; latihan membentuk, meluruskan, atau menyempurnakan sesuatu sebagai kemampuan mental atau karakter moral; hukuman yang diberikan untuk melatih 
atau memperbaiki; kumpulan atau sistem peraturan-peraturan bagi tingkah laku ${ }^{10}$.

Ajaran Islam sangat menganjurkan kepada manusia untuk selalu belajar. Bahkan Islam mewajibkan kepada setiap orang beriman untuk belajar. Dalam Islam pendidikan tidak hanya dilaksanakan dalam batasan waktu tertentu saja, melainkan dilakukan sepanjang usia (long life education). Namun ajaran Islam menekankannya jadi signifikansi kognitif (akal) dan sensori (indera-indera) sebagai alat-alat penting untuk belajar, sangat jelas katakata kunci seperti ya'qilun, yatafakkarun, yasma'un, dan sebagainya yang terdapat dalam Al-Qur'an, hal tersebut merupakan bukti betapa pentingnya pengaruh ranah/cipta dan karsa manusia dalam belajar dan meraih ilmu pengetahuan. Dalam ajaran Islam, baik secara eksplisit maupun implisit mewajibkan ummatnya untuk belajar agar memperoleh ilmu pengetahuan.

Sebagaimana Allah Subhaanahu Wa Ta'ala berfirman dalam Al-Qur'an Surat Az-Zumar ayat 9:

\section{"Katakanlah (wahai Muhammad) apakah sama orang-orang yang mengetahui dan orang-orang yang tidak mengetahui. Sesungguhnya}

10 Tu'u Tulus. 2004. Peran Displin pada Perilaku dan Prestasi Siswa. Jakarta: Grasindo. hlm. 91. orang yang berakallah yang dapat menerima pelajaran. (QS Az

Zumar: 9)

Terkait dengan ayat di atas, Muhibbin Syah (2014) berpendapat bahwa secara rasional semua ilmu pengetahuan dapat diperoleh melalui belajar. Maka, "belajar adalah "key term" (istilah kunci) yang paling vital dalam usaha pendidikan. Sehingga, tanpa belajar sesungguhnya tidak pernah ada pendidikan". ${ }^{11}$ Muhibbin Syah menambahkan, bahwa kemampuan untuk belajar merupakan sebuah karunia Allah yang mampu membedakan manusia dangan makhluk yang lain. Allah menghadiahkan akal kepada manusia untuk mampu belajar dan menjadi pemimpin di dunia ini. Belajar adalah perubahan tingkah laku yang relatif menetap sebagai hasil pengalaman dan interaksi dengan lingkungannya. ${ }^{12}$

Dengan demikian, belajar memiliki peranan yang sangat penting dalam kehidupan manusia. Memang manusia terlahir sebagai mahluk yang lemah yang tidak mampu berbuat apa-apa serta tidak mengetahui apa-apa. Akan tetapi melalui proses belajar itu dalam fase perkembangannya, manusia bisa menguasai skill (kemahiran/ keterampilan) maupun pengetahuan.

Sesungguhnya kemampuan untuk belajar dan melakukan berbagai upaya uji coba, termasuk kemampuan adaptasi terhadap aneka situasi yang dimiliki

\footnotetext{
${ }^{11}$ Muhibbin Syah. 2004. Psikologi Belajar. Jakarta: PT. RajaGrafindo Persada. hlm. 59.

${ }^{12}$ Muhibbin Syah. 2004. hlm. 68.
} 
manusia maupun hewan. Kemampuan adaptasi inilah yang membantu kedua mahluk tersebut bisa hidup dan berada di muka bumi. Manusia tidak hanya mempelajari bahasa, ilmu pengetahuan, profesi, maupun keahlian tertentu saja. Sesungguhnya manusia juga mempelajari berbagai macam tradisi, etika, moral, dan kepribadian seseorang. Oleh karena itu, belajar memiliki peranan yang sangat penting dalam kehidupan manusia. Urgensi proses belajar telah ditegaskan semenjak diturunkannya ayat pertama dalam AlQuran al-Karim. Allah Subhannahu Wa Ta'ala berfirman dalam Surat Al-'Alaq: 1-5 : "Bacalah dengan (menyebut) nama Tuhanmu yang Menciptakan. Dia telah menciptakan manusia dari segumpal darah. Bacalah, dan Tuhanmulah yang Maha pemurah. Yang mengajar (manusia) dengan perantaran kalam. Dia mengajar kepada manusia apa yang tidak diketahuinya".

Ayat tersebut erat kaitannya dengan masalah perintah kepada manusia agar setiap muslim menggali pengetahuan melalui proses belajar membaca dan menulis. Karena belajar merupakan proses dasar dari perkembangan hidup manusia. Dengan belajar, manusia melakukan perbuatan-perbuatan kualitatif, baik secara individu maupun sosial, sehingga tingkah lakunya berkembang. Semua aktivitas dan prestasi hidup manusia tidak lain adalah dari proses belajar.

Setiap manusia di dalam mengisi aktivitas hidupnya senantiasa melakukan suatu perbuatan menurut apa yang telah dipelajari dari pengalaman dan interaksi dengan lingkungannya yang melibatkan proses kognitif. Akan tetapi belajar itu bukan sekedar pengalaman. Belajar adalah suatu proses dan bukan suatu hasil, maka belajar merupakan kegiatan yang berproses dan merupakan unsur yang sangat fundamental dalam setiap penyelenggaraan jenis dan jenjang pendidikan. Ini berarti bahwa berhasil atau gagalnya pencapaian tujuan pendidikan itu sangat tergantung pada proses belajar yang dialami peserta didik, baik ketika peserta didik berada di sekolah maupun di lingkungan rumah atau keluarganya sendiri.Karena itulah belajar berlangsung secara aktif dan integratif dengan menggunakan berbagai bentuk perbuatan untuk mencapai suatu tujuan.

Tujuan belajar dalam dunia pendidikan sekarang ini lebih dikenal dengan tujuan pendidikan. Menurut Bloom dalam Alisuf Sabri dijelaskan bahwa tujuan belajar peserta didik diarahkan untuk mencapai ketiga tanah antara lain: kognitif, psikomotorik dan afektif. Tujuan belajar kognitif untuk memperoleh fakta atau ingatan, pemahaman, aplikasi dan kematangan berpikir analisis, sistematis dan evaluasi.Tujuan belajar afektif untuk memperoleh sikap, apresiasi, karakteristik, dan tujuan psikomotorik untuk memperoleh keterampilan fisik yang berkaitan dengan keterampilan gerak maupun keterampilan ekspresi verbal dan non verbal. ${ }^{13}$

13 Alisuf Sabri. 2006. Psikologi Pendidikan. Jakarta: Pedoman Ilmu Jaya. hlm. 58-59. 
Dengan demikian, proses belajar itu sendiri adalah aktivitas diri yang melibatkan aspek-aspek "sosio psiko fisik" dalam upaya menuju tercapainya tujuan belajar, yakni terjadinya perubahan tingkah laku. Terkait hal ini, Nana Syaodih dan Sukmadinata mengemukakan tujuh unsur utama dalam proses belajar yaitu; tujuan, kesiapan, situasi, interpretasi (melihat hubungan di antara komponen-komponen situasi belajar, melihat makna dari hubungan tersebut, dan menghubungkan dengan kemungkinan pencapaian tujuan), respons, konsekuensi (keberhasilan atau kegagalan dalam belajar), dan reaksi terhadap kegagalan. ${ }^{14}$

Berdasarkan pendapat ahli di atas dapat disimpulkan bahwa tujuan utama dari proses belajar adalah guna memudahkan mencapai hasil belajar serta menggunakan hasil belajarnya tersebut tidak hanya semata atau tergantung pada dirinya sendiri tapi perlu adanya dukungan dari berbagai faktor baik eksternal maupun internal untuk menunjang peserta didik dalam belajar mencapai hasil belajar serta menggunakan hasil belajarnya.

\section{Upaya Guru dalam Meningkatkan Disiplin Belajar}

Guru sebagai pendidik mempunyai peranan penting dalam mengembangkan disiplin diri peserta didik. Pada saat proses pembelajaran berlangsung, para guru dituntut untuk dapat melakukan kontrol eksternal dengan melakukan tindakan-tindakan yang dapat

14 Nana Syaodih, Sukmadinata.2009. Landasan Psikologi Proses Pendidikan. PT. Remaja Rosdakarya bandung. hlm. 157. membentuk "self discipline pada peserta didik, sehingga diharapkan peserta didik dapat mentaati peraturan, norma, dan batasan-batasan perilaku dirinya. Upaya untuk mengembangkan disiplin diri adalah melalui penanaman disiplin. Dengan penanaman disiplin ini guru berusaha menciptakan situasi proses belajar mengajar yang dapat mendorong peserta didik untuk berdisiplin diri dalam belajarnya.

Pengembangan disiplin oleh guru cenderung dilakukan di dalam kelas, oleh karena itu selanjutnya timbul pertanyaan: Kelas yang bagaimana yang dikatakan disiplin? Untuk menjawab pertanyaan ini, salah satunya dapat menyimak apa yang dikatakan William Gnagey bahwa:

"Good discipline refers to a situation in which your students are exerting an optimal amount of energy trying to learn what you want to teach them instead of wasting it in various other counter productive activities". 15

Pernyataan di atas memperlihatkan bahwa disiplin akan terbentuk apabila setiap peserta didik memiliki motivasi yang kuat untuk melibatkan diri secara aktif dalam proses pembelajaran. Dengan kata lain, tanpa partisipasi peserta didik (melalui motivasi yang kuat), apapun yang diupayakan guru dalam mengembangkan disiplin belajar tidak akan berhasil secara optimal.

Untuk menanamkan disiplin pada peserta didik, ada beberapa hal yang perlu menjadi perhatian guru, di antaranya; a) Guru hendaknya menjadi

15 http://motivasi-belajar-dan-disiplinunmul.blogspot.co.id/, diakses tanggal 25 April 2017 pukul 23.50 WIB. 
model bagi peserta didik, b) Guru hendaknya memahami dan menghargai pribadi peserta didik, c) Guru memberikan bimbingan kepada peserta didik, mengembangkan iklim kelas dan bersuasana tenang yang membantu peserta didik bebas dari ketegangan, mengadakan dialog tentang tujuan dan manfaat peraturan belajar yang ditetapkan sekolah (guru) dengan peserta didik, d) Membantu peserta didik untuk mengembangkan kebiasaan belajar yang baik, e) Membantu mengembangkan sikap positif peserta didik terhadap belajar, f) Membantu peserta didik yang mengalami masalah, terutama masalah belajar, dan g) Memberikan informasi tentang nilai-nilai yang berlaku, dan mendorong peserta didik agar berperilaku sesuai dengan nilai-nilai tersebut. ${ }^{16}$

Dengan demikian, disiplin sangat diperlukan dalam proses belajar baik itu di sekolah maupun di rumah. Dari disiplin yang dilakukan seorang itulah yang merupakan salah satu diantara yang mempengaruhi hasil dan prestasi belajar peserta didik.

\section{METODE PENELITIAN}

Tempat penelitian ini dilaksanakan di Sekolah Menengah Kejuruan (SMK) Analis Kimia YKPI yang berlokasi di Jalan H. Achmad Sobana, SH. (Bangbarung) Perumnas Bantarjati, Kota Bogor, Jawa Barat.

Adapun waktu penelitian ini telah dilaksanakan selama empat bulan dari

16 https://id.wikipedia.org/wiki/tujuandisiplin-sekolah, diakses tanggal 26 April2017 pukul 11.30 WIB. bulan April hingga 30 Agustus 2016. Jenis penelitian ini menggunakan metode kuantitatif. Metode kuantitatif dinamakan metode tradisional, karena metode ini sudah cukup lama digunakan sehingga sudah mentradisi sebagai metode untuk penelitian. Metode ini disebut sebagai metode positivistik karena berlandaskan pada pada filsafat positivisme. Metode ini sebagai metode ilmiah/scientic karena telah memenuhi kaidah-kaidah ilmiah yaitu konkrit/empiris, obyektif, terukur, rasional, dan sistematis. Metode ini juga disebut discovery karena dengan metode ini dapat ditemukan dan dikembangkan berbagai iptek baru. Metode ini disebut metode kuantitatif karena data penelitian berupa angka-angka dan analisis menggunakan statistik. ${ }^{17}$

Peneliti melakukan penelitian kepada sejumlah subjek dan objek penelitian, yaitu para peserta didik kelas $\mathrm{X}$ dan XII yang berjumlah 320 orang. Dari jumlah populasi tersebut peneliti mengambil sampel secara random sebanyak 57 responden yang dijadikan objek penelitian mengingat jumlah objek yang diteliti cukup banyak. Teknik pengumpulan data menggunakan konsep Sugiyono, yaitu melalui teknik dokumentasi, observasi, dan kuesioner (angket) dan gabungan ketiganya. ${ }^{18}$ Kuesioner sebelumnya diujicobakan dulu sebelum digunakan untuk penelitian untuk diuji validitasnya dengan rumus Product Moment Pearson dan diuji realibilitasnya dengan rumus Alpha

17 Sugiyono. 2009. Metode Penelitian Kuantitatif Kualitatif dan $R$ \& D. Bandung: Alfabeta. hlm. 7.

${ }^{18}$ Sugiyono, 2009. hlm. 137. 
Cronbach. Analisis data menggunakan analisis statistik deskriptif. Dalam menganalisis data digunakan teknik skoring berdasarkan kuisioner yang disebarkan kepada responden berdasarkan skala model Likert yang berisi sejumlah pertanyaan yang menyatakan objek yang hendak diungkap. Penskoran atas kuesioner menggunakan skala model Likert.

Dalam penelitian ini, untuk mengetahui ada tidaknya pengaruh antara penggunaan sosial media wathshapp terhadap kedisiplinan peserta didik pada mata pelajaran Pendidikan Agama Islam, maka pengolahan data penelitian ini menggunakan rumus analisis Korelasi Product Moment. Variabel yang diujikan adalah korelasi antar dua variabel yang terdiri dari dependent varibel yaitu varibel yang terikat atau variabel yang dipengaruhi dan independent variabel atau disebut juga variabel bebas. Karena penelitian ini membahas dua variabel yang diteliti untuk selanjutnya dilakukan tabulasi data, diolah dengan rumus statistik dan dilakukan analisis. Adapun teknik analisis data yang dilakukan melalui beberapa tahapan, yaitu dengan cara mencari angka korelasi dengan rumus dari Karl Pearson di bawah ini:

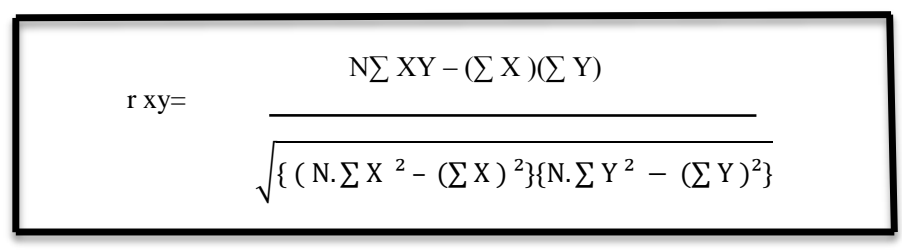

Keterangan:

$$
\begin{array}{ll}
\mathrm{Rxy} & =\text { Angka Indek Korelasi " } \mathrm{r} \text { " Product Moment } \\
\mathrm{N} & =\text { Number of sample } \\
\sum \mathrm{xy} & =\text { Jumlah hasil perkalian antara skor } \mathrm{X} \text { dan } \mathrm{Y} \\
\sum X & =\text { Jumlah skor } \mathrm{X} \\
\sum Y & =\text { Jumlah skor } \mathrm{Y}
\end{array}
$$

Setelah data diolah dengan rumus di atas, maka dialakukan interprestasi data terhadap $\mathrm{r}$ x y interprestasi sederhana dengan mencocokan hasil hitungan dengan angka indek pengaruh " $r$ " Pearson Product Moment.

Untuk mengetahui sejauh mana hubungan antara variabel bebas dan variabel terikat maka dilakukan uji signifikasi dengan rumus: ${ }^{19}$

$$
t=\frac{\mathrm{r}=\sqrt{\mathrm{n}-2}}{\sqrt{1-r^{2}}}
$$

\footnotetext{
${ }^{19}$ Darwansyah, dkk. 2010. Pengantar Statistik Pendidikan. Jakarta: GP Press. hlm. 98.
} 
$\mathrm{r}=$ Nilai koefisien korelasi
$\mathrm{n}=$ Jumlah sampel

Selanjutnya peneliti melakukan interpretasi data yaitu dengan angka indek korelasi yang dijadikan patokan untuk mengetahui besar kecilnya kekuatan pengaruh (kuat, lemah, atau tidak ada) diantara variabel yang diteliti. Dalam masalah ini ada dua macam cara dapat ditempuh, yaitu; 1) Interpretasi secara sederhana, dan 2) Interpretasi dengan menggunakan nilai "r" Pearson Product Moment.

Adapun yang dimaksud interpretasi secara sederhana yaitu melihat tingkat keeratan korelasi atau korelasi atau pengaruh antar variabel dapat dilhat dari angka koefisien korelasi yang disajikan dalam bentuk tabel interprestasi koefisien korelasi sebagai berikut: ${ }^{20}$

Tabel 1

Interpretasi Koefisien Korelasi/Pengaruh

\begin{tabular}{|c|l|}
\hline Nilai Koefisien Korelasi & \multicolumn{1}{|c|}{ Interpretasi } \\
\hline $\mathrm{Kk}=0$ & $\begin{array}{l}\text { Pengaruh sangat lemah atau tidak ada pengaruh } \\
\text { sama sekali }\end{array}$ \\
\hline $0,<\mathrm{kk} ? 0,20$ & $\begin{array}{l}\text { Pengaruh rendah/lemah tapi pasti antara } \\
\text { variabel } \mathrm{X} \text { dan variabel } \mathrm{Y} \text { memang terdapat } \\
\text { pengaruh tetapi lemah atau rendah jadi } \\
\text { diabaikan }\end{array}$ \\
\hline $0,20<\mathrm{kk} ? 0,40$ & $\begin{array}{l}\text { Pengaruh yang cukup berarti antara variabel } \mathrm{X} \\
\text { dan Y ada pengaruh yang lemah }\end{array}$ \\
\hline $0,40<\mathrm{kk} ? 0,70$ & $\begin{array}{l}\text { Pengaruh yang cukup berarti antara variabel } \mathrm{X} \\
\text { dan Y ada pengaruh yang sedang atau cukup }\end{array}$ \\
\hline $0,70<\mathrm{kk} ? 0,90$ & $\begin{array}{l}\text { Pengaruh sangat tinggi, kuat sekali, sangat } \\
\text { diandalkan antara varabel X da Y ada pengaruh } \\
\text { yang cukup berarti atau cukup tinggi }\end{array}$ \\
\hline $\mathrm{Kk}=1$ & $\begin{array}{l}\text { Pengaruh sempurna antara variabel } \mathrm{X} \text { dan } \mathrm{Y} \\
\text { terdapat korelasi/pengaruh yang sempurna }\end{array}$ \\
\hline
\end{tabular}

${ }^{20}$ Darwansyah dkk. 2010. hlm. 93. 
Sedangkan yang dimaksud interpretasi dengan menggunakan nilai "r" Pearson Product Moment, yaitu dengan cara menguji kebenaran dan kepalsuan yang telah dumuskan dengan cara membandingkan nilai ' $r$ ' yang telah diperoleh dari perhitungan, dengan nilai yang tercantum dalam nilai $\mathrm{r}$ tabel (rt) Pearson Product Moment, dengan terlebih dahulu mencari derajat bebas $(\mathrm{db})$ atau degree of freedom dengan menggunakan rumus yaitu:

$$
\begin{aligned}
& \mathrm{df}=\mathrm{N}-\mathrm{nr} \\
& \mathrm{df}=\text { Degree of freedom } \\
& \mathrm{N}=\text { Number of sample } \\
& \mathrm{Nr}=\text { Banyaknya variabel yang }
\end{aligned}
$$
dikorelasikan

Dengan diperoleh nilai df maka dicari besarnya " $r$ " yang tercantum tabel nilai "r" Pearson Product Moment, pada taraf signifiksai $5 \%$. Berdasarkan rekap data hasil penelitian variabel penggunaan sosial media whatsapp diperoleh:

$$
\begin{aligned}
\text { Rentangan } & \\
& =\text { Skor Terbesar } \\
& - \text { Skor Terkecil } \\
= & 85-58 \\
= & 27
\end{aligned}
$$

$$
\begin{aligned}
\text { Banyak Kelas } & =1+3,3(\log n) \\
& =1+3,3(1,756) \\
& =1+5,79
\end{aligned}
$$

Jika nilai $\mathrm{r}_{\text {hitung }}$ lebih besar dari $\mathrm{r}_{\text {tabel }}$ maka (Ha) hipotesa alternatif disetujui atau diterima, dan sebaliknya hipotesa nol (Ho) tidak disetujui atau ditolak.

\section{HASIL DAN PEMBAHASAN}

Data hasil penelitian ini adalah data yang diperoleh berdasarkan rekap data isian responden terhadap kuesioner yang disebar setelah dilakukan uji validitas dan reliabilitas. Sebelum dilakukan pengujian hipotesis, terlebih dahulu dilakukan uji persyaratan data dengan uji normalitas dan uji linieritas. Uji normalitas dilakukan untuk mengetahui data yang digunakan berasal dari populasi yang berdistribusi normal. Sedangkan uji linieritas dilakukan untuk memperoleh persamaan dan besaran nilai $F$, sehingga dapat diketahui bahwa $\mathrm{F}$ memiliki model regresi linier sederhana.

$$
\text { =6,79 dibulatkan } 7
$$

$$
\begin{aligned}
\text { Panjang Kelas } & =\frac{\text { Rentangan }}{\text { Banyak Kelas }} \\
& =\frac{27}{7} \\
& =3,97 \text { dibulatkan } 4
\end{aligned}
$$

Tabel 2

Distribusi Frekuensi Variabel Penggunaan Sosial Media WhatsApp 


\begin{tabular}{|c|c|c|r|c|r|}
\hline $\mathrm{Ci}$ & $\mathrm{fi}$ & $\mathrm{Xi}$ & \multicolumn{1}{c|}{ fiXi } & \multicolumn{1}{c|}{$\mathrm{Xi}^{2}$} & \multicolumn{1}{c|}{ fiXi $^{2}$} \\
\hline $82-85$ & 9 & 83,50 & 751,50 & 6972,25 & 62750,25 \\
\hline $78-81$ & 16 & 79,50 & 1272,00 & 6320,25 & 101124,00 \\
\hline $74-77$ & 11 & 75,50 & 830,50 & 5700,25 & 62702,75 \\
\hline $70-73$ & 5 & 71,50 & 357,50 & 5112,25 & 25561,25 \\
\hline $66-69$ & 9 & 67,50 & 607,50 & 4556,25 & 41006,25 \\
\hline $62-65$ & 5 & 63,50 & 317,50 & 4032,25 & 20161,25 \\
\hline $58-61$ & 2 & 59,50 & 119,00 & 3540,25 & 7080,50 \\
\hline$\Sigma$ & 57 & & 4255,50 & & 320386,25 \\
\hline
\end{tabular}

$$
\begin{aligned}
\text { Mean } & =\frac{\sum f i X i}{\sum f i} \\
& =\frac{4255,50}{57} \\
& =74,66
\end{aligned}
$$

Median $=b+p\left[\frac{\left(\frac{1}{2} n-f_{1}\right)}{f_{2}}\right]$

$$
\begin{array}{r}
=77,50 \\
+4\left[\frac{(28,50-32)}{9}\right]
\end{array}
$$$$
=77,50+4\left[\frac{-3,50}{9}\right]
$$$$
=77,50+4[-0,39]
$$$$
=77,50+(-1,55)
$$$$
=75,95
$$

Modus $=b+p\left[\frac{b_{1}}{b_{1}+b_{2}}\right]$

$$
\begin{aligned}
& =77,50+4\left[\frac{5}{5+7}\right] \\
& =77,50+4\left[\frac{5}{12}\right] \\
& =77,50+4[0,42] \\
& =77,50+1,68 \\
& =79,18
\end{aligned}
$$

Standar Deviasi

$$
=\sqrt{\frac{n \cdot \sum f i X i^{2}-\left(\sum f i X i\right)^{2}}{n \cdot(n-1)}}
$$

$$
=\sqrt{\frac{57.320386,25-18109280,25}{57 \cdot(57-1)}}
$$$$
=\sqrt{\frac{57.320386,25-18109280,25}{57.49}}
$$

$$
\begin{aligned}
=\sqrt{\frac{18262016,25}{3192}-18109280,25} \\
=\sqrt{\frac{152736}{3192}} \\
=\sqrt{47,85} \\
=6,92
\end{aligned}
$$

Mencari nilai $\mathrm{L}_{\text {hitung }}$ responden nomor urut pertama:

$$
\begin{gathered}
Z_{i}=\frac{\text { Angka }- \text { Mean }}{\text { Standar Deviasi }} \\
=\frac{58-74,66}{6,92} \\
=(2,41) \\
\quad F\left(Z_{i}\right)=0,0080 \\
S\left(Z_{i}\right)=0,0175 \\
F\left(Z_{i}\right)-S\left(Z_{i}\right)=(0,0095)
\end{gathered}
$$


Dengan cara yang sama dilakukan uji normalitas data responden urutan dua sampai dengan 57. Kemudian berdasarkan tabel uji normalitas, diketahui nilai $\mathrm{t}$ hitung sebesar -0,0681 jika dikonsultasikan dengan $t_{\text {tabel }}$ untuk sampel 57 diperoleh nilai kritis untuk $\alpha$ $(0,05)$ sebesar 0,117 dan nilai kritis untuk $\alpha(0,01)$ sebesar 0,137 . Maka data variabel disiplin belajar diketahui $\mathrm{t}$ hitung $<\mathrm{t}$ tabel pada taraf kesalahan 5\% (0,0681< 0,117), maka Ho ditolak. Dengan demikian data variabel penggunaan sosial media whatsapp berasal dari populasi yang berdistribusi normal.

Selanjutnya dilakukan untuk mengetahui ketepatan hubungan dan

pada mata pelajaran Pendidikan Agama Islam di SMK Analis Kimia YKPI Bogor". memprediksi besarnya arah hubungan itu dengan model regresi sederhana. Berdasarkan uji linearitas, diketahui bahwa $F_{\text {hitungb }}>$ b $\alpha(0,05)<F_{\text {tabel }}=0,85$ $>0,05<1,93$ maka $\mathrm{H}_{\mathrm{o}}$ ditolak. Dengan demikian pengaruh penggunaan sosial media whatsapp terhadap disiplin belajar memiliki model regresi sederhana.

Langkah selanjutnya adalah pengujian hipotesis (pengolahan data) dilakukan untuk menjawab hipotesis penelitian yang diajukan, yaitu: "Terdapat pengaruh positif dan signifikan penggunaan sosial media whatsapp terhadap disiplin belajar peserta didik kelas $\mathrm{X}$

Tabel 3

Kerja Uji Hipotesis

\begin{tabular}{|c|c|c|c|c|c|}
\hline NR & $\mathbf{X}$ & $\mathbf{Y}$ & $\mathbf{X}^{2}$ & $\mathbf{Y}^{2}$ & $\mathbf{X Y}$ \\
\hline 1 & 73 & 72 & 5329 & 5184 & 5256 \\
\hline 2 & 83 & 79 & 6889 & 6241 & 6557 \\
\hline 3 & 78 & 75 & 6084 & 5625 & 5850 \\
\hline 4 & 78 & 75 & 6084 & 5625 & 5850 \\
\hline 5 & 84 & 80 & 7056 & 6400 & 6720 \\
\hline 6 & 58 & 56 & 3364 & 3136 & 3248 \\
\hline 7 & 76 & 74 & 5776 & 5476 & 5624 \\
\hline 8 & 83 & 79 & 6889 & 6241 & 6557 \\
\hline 9 & 69 & 70 & 4761 & 4900 & 4830 \\
\hline 10 & 82 & 78 & 6724 & 6084 & 6396 \\
\hline 11 & 76 & 72 & 5776 & 5184 & 5472 \\
\hline 12 & 84 & 80 & 7056 & 6400 & 6720 \\
\hline 13 & 74 & 74 & 5476 & 5476 & 5476 \\
\hline 14 & 75 & 71 & 5625 & 5041 & 5325 \\
\hline 15 & 85 & 77 & 7225 & 5929 & 6545 \\
\hline 16 & 62 & 53 & 3844 & 2809 & 3286 \\
\hline 17 & 80 & 76 & 6400 & 5776 & 6080 \\
\hline 18 & 79 & 76 & 6241 & 5776 & 6004 \\
\hline 19 & 67 & 59 & 4489 & 3481 & 3953 \\
\hline 20 & 77 & 75 & 5929 & 5625 & 5775 \\
\hline
\end{tabular}


Jurnal Edukasi Istami Jumal Pendidilkan Islam Vol. 07/No.1, April 2018

\begin{tabular}{|c|c|c|c|c|c|}
\hline 21 & 69 & 64 & 4761 & 4096 & 4416 \\
\hline 22 & 83 & 78 & 6889 & 6084 & 6474 \\
\hline 23 & 67 & 60 & 4489 & 3600 & 4020 \\
\hline 24 & 77 & 73 & 5929 & 5329 & 5621 \\
\hline 25 & 80 & 76 & 6400 & 5776 & 6080 \\
\hline 26 & 67 & 65 & 4489 & 4225 & 4355 \\
\hline 27 & 71 & 65 & 5041 & 4225 & 4615 \\
\hline 28 & 82 & 77 & 6724 & 5929 & 6314 \\
\hline 29 & 68 & 65 & 4624 & 4225 & 4420 \\
\hline 30 & 80 & 76 & 6400 & 5776 & 6080 \\
\hline 31 & 77 & 73 & 5929 & 5329 & 5621 \\
\hline 32 & 64 & 65 & 4096 & 4225 & 4160 \\
\hline 33 & 76 & 73 & 5776 & 5329 & 5548 \\
\hline 34 & 65 & 65 & 4225 & 4225 & 4225 \\
\hline 35 & 81 & 77 & 6561 & 5929 & 6237 \\
\hline 36 & 64 & 66 & 4096 & 4356 & 4224 \\
\hline 37 & 73 & 69 & 5329 & 4761 & 5037 \\
\hline 38 & 77 & 72 & 5929 & 5184 & 5544 \\
\hline 39 & 65 & 67 & 4225 & 4489 & 4355 \\
\hline 40 & 81 & 77 & 6561 & 5929 & 6237 \\
\hline 41 & 66 & 68 & 4356 & 4624 & 4488 \\
\hline 42 & 76 & 72 & 5776 & 5184 & 5472 \\
\hline 43 & 78 & 72 & 6084 & 5184 & 5616 \\
\hline 44 & 66 & 67 & 4356 & 4489 & 4422 \\
\hline 45 & 83 & 78 & 6889 & 6084 & 6474 \\
\hline 46 & 77 & 72 & 5929 & 5184 & 5544 \\
\hline 47 & 72 & 69 & 5184 & 4761 & 4968 \\
\hline 48 & 72 & 69 & 5184 & 4761 & 4968 \\
\hline 49 & 80 & 76 & 6400 & 5776 & 6080 \\
\hline 50 & 80 & 76 & 6400 & 5776 & 6080 \\
\hline 51 & 68 & 68 & 4624 & 4624 & 4624 \\
\hline 52 & 79 & 76 & 6241 & 5776 & 6004 \\
\hline 53 & 78 & 72 & 6084 & 5184 & 5616 \\
\hline 54 & 80 & 76 & 6400 & 5776 & 6080 \\
\hline 55 & 60 & 66 & 3600 & 4356 & 3960 \\
\hline 56 & 81 & 77 & 6561 & 5929 & 6237 \\
\hline 57 & 79 & 75 & 6241 & 5625 & 5925 \\
\hline$\sum$ & 4265 & 4083 & 321799 & 294523 & 307665 \\
\hline
\end{tabular}


Berdasarkan tabel di atas diketahui:

$$
\begin{aligned}
& =\frac{17536905-17413995}{\sqrt{\{18342543-18190225\} .\{16787811-16670889\}}} \\
& =\frac{122910}{\sqrt{\{152318\} .\{116922\}}} \\
& =\frac{122910}{\sqrt{17809325196}} \\
& =\frac{122910}{133451,584} \\
& =\mathbf{0}, \mathbf{9 2 1}
\end{aligned}
$$

$$
\begin{aligned}
& =321799 \\
& =294523
\end{aligned}
$$$$
\sum Y^{2}
$$

$$
\begin{aligned}
& \left(\sum X\right)^{2} \\
& =18190225 \\
& =16670889
\end{aligned}
$$

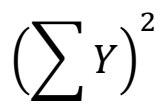

Tahapan-tahapan dalam pengujian hipotesis (pengolahan data) sebagai berikut:

\section{Uji Koefisien Korelasi}

Uji Koefisien Korelasi dilakukan untuk mengetahui keeratan atau keberartian hubungan kedua variabel, dengan menggunakan rumus koefisien korelasi dari Spearman:

$$
=\frac{r_{x y}}{\sqrt{\left\{n \cdot \sum X^{2}-\left(\sum X\right)^{2}\right\} \cdot\left\{n \cdot \sum Y^{2}-\left(\sum Y\right)^{2}\right\}}}
$$

\section{Uji Koefisien Determinasi}

Uji koefisien determinasi menerangkan seberapa besar variasi $\mathrm{Y}$ yang disebabkan oleh $\mathrm{X}$. Rumus yang digunakan adalah:

$$
\begin{array}{rl}
R^{2}=\left(r_{x y}\right)^{2} \cdot 1 & 00 \% \\
& =(0,921)^{2} \cdot 100 \% \\
& =0,848 \cdot 100 \% \\
& =84,8 \%
\end{array}
$$

\section{Uji Signifikansi Korelasi}

Uji-t berguna untuk menguji signifikansi korelasi, apakah variabel independen berpengaruh secara nyata (positif) atau tidak terhadap variabel dependen. Rumus yang digunakan adalah:

$$
t_{\text {hit }}=\frac{r_{x y} \cdot \sqrt{n-2}}{\sqrt{1-\left(r_{x y}\right)^{2}}}
$$

$$
=\frac{(57.307665)-(4265 \cdot 4083)}{\sqrt{\{57.321799-18190225\} .\{57 \cdot 294523-16670889\}}}=\frac{0,921 \cdot \sqrt{57-2}}{\sqrt{1-(0,921)^{2}}}
$$




$$
\begin{aligned}
& =\frac{0,921 \cdot \sqrt{55}}{\sqrt{1-0,848}} \\
& =\frac{0,921 \cdot 7,416}{\sqrt{1-0,848}}
\end{aligned}
$$

\section{Temuan dan Pembahasan}

Nilai koefisien korelasi yang diinterpretasikan secara kasar atau sederhana dengan mencocokan hasil perhitungan dengan angka indeks korelasi " $r$ " product moment. Ternyata besarnya $r_{x y}(0,921)$ yang besarnya berkisar antara 0,81-1,00 berarti korelasi antara penggunaan sosial media whatsapp memiliki pengaruh yang sangat kuat dengan disiplin belajar peserta didik pada mata pelajaran Pendidikan Agama Islam di SMK Analis Kimia YKPI Bogor.

Terdapat pengaruh penggunaan sosial media whatsapp terhadap disiplin belajar peserta didik yang positif. Hal ini dikarenakan banyak peserta didik yang menggunakan sosial media whatsapp di saat jam pelajaran berlangsung, sehingga disiplin belajar peserta didik menjadi lemah dan tidak fokus dalam mengikuti pembelajaran.

Interpretasi terhadap $r_{x y}$ dengan jalan berkonsultasi pada nilai " $r$ " product moment dengan jalan:

a. Dikemukakan kembali hipotesis penelitian, yaitu:

1). Hipotesis nol, disingkat (Ho)

Ho: Tidak terdapat pengaruh positif yang signifikan antara

$$
\begin{aligned}
& =\frac{6,83}{\sqrt{0,152}} \\
& =\frac{6,83}{0,39}=17,53
\end{aligned}
$$

penggunaan sosial media whatsapp terhadap disiplin belajar.

2). Hipotesis kerja atau disebut dengan hipotesis alternatif (Ha)

Ha: Terdapat pengaruh positif yang signifikan antara penggunaan sosial media whatsapp terhadap disiplin belajar.

b. Menguji kebenaran dan hipotesis yang telah dirumuskan dengan jalan membandingkan besarnya " $r$ " product moment dengan "r" yang tercantum dalam tabel "r". Secara operasional analisis data, ternyata angka korelasi antara variabel $\mathrm{X}$ dan variabel $\mathrm{Y}$ bertanda positif dengan memperhatikan besarnya rxy yang diperoleh yaitu sebesar 0,921. Kemudian pada taraf signifikan 5\% diperoleh nilai " $r$ " tabel sebesar 0,266 dan pada taraf signifikan $1 \%$ diperoleh nilai sebesar 0,345 ternyata rxy yang besarnya 0,921 adalah jauh lebih tinggi daripada " $r$ " tabel yang besarnya 0,266 dan 0,345. Karena rxy lebih tinggi dari " $r$ " tabel, dengan demikian hipotesis Nol (Ho) ditolak dan hipotesis alternatif (Ha) diterima. Dengan demikian pengaruh positif yang sangat kuat antara penggunaan sosial media whatsapp terhadap disiplin belajar peserta didik kelas $\mathrm{X}$ pada mata pelajaran Pendidikan 
Agama Islam di SMK Analis Kimia YKPI Bogor.

c. Menguji koefisien
determinasi untuk mengetahui seberapa besar variasi $\mathrm{Y}$ yang disebabkan oleh $X$. Nilai $R$ Square $\left(R^{2}\right)$ menunjukkan variasi yang terjadi terhadap disiplin belajar disebabkan oleh penggunaan sosial media whatsapp. Diperoleh nilai $\mathrm{R}$ Square $\left(R^{2}\right)$ sebesar 0,848 menunjukkan peningkatan disiplin belajar dapat dipengaruhi oleh penggunaan sosial media whatsapp sebesar $84,8 \%$ dan sisanya dipengaruhi oleh hal-hal lain di luar persamaan ini.

d. Dari hasil uji signifikansi korelasi diperoleh nilai $t_{\text {hitung }}$ sebesar 17,53 jika dikonsultasikan dengan $\mathrm{t}_{\text {tabel }} \alpha(0,05)$ dan $\alpha(0,01)$ dengan $\mathrm{n}=$ 57 mendekati nilai puluhan 60 diperoleh $t_{\text {tabel }}$ sebesar 1,671 dan 2,000. Diketahui $t$ hitung $>t_{\text {tabel }}$ yaitu: $17,53>1,671$ dan 2,000 maka Ho ditolak, artinya penggunaan sosial media whatsapp berpengaruh secara nyata (signifikan) terhadap disiplin belajar. Sedangkan pada taraf signifikansi $5 \%$ nilai $t_{\text {hitung }}$ jauh lebih tinggi dari $t_{\text {tabel }}$ yaitu: 17,53>1,671.

Berdasarkan interpretasi di atas maka hasil penelitian ini berhasil menjawab hipotesis yang diajukan yaitu: "Terdapat pengaruh positif dan signifikan penggunaan sosial media whatsapp terhadap disiplin belajar peserta didik kelas $\mathrm{X}$ pada mata pelajaran Pendidikan Agama Islam di SMK Analis Kimia YKPI Bogor".
Dengan kata lain, hasil penelitian ini menerima hipotesis alternatif (Ha) dan menolak hipotesis nol (Ho).

\section{E. PENUTUP}

Berdasarkan hasil penelitian yang telah dilakukan peneliti tentang ada tidaknya pengaruh penggunaan sosial media whatsapp terhadap disiplin belajar peserta didik kelas $\mathrm{X}$ pada mata pelajaran Pendidikan Agama Islam di SMK Analis Kimia YKPI Bogor, dapat diambil kesimpulan, bahwa terdapat pengaruh yang sangat kuat antara penggunaan sosial media whatsapp terhadap disiplin belajar peserta didik pada mata pelajaran Pendidikan Agama Islam yang positif. Hal ini dikarenakan banyak peserta didik yang menggunakan sosial media whatsapp di saat jam pelajaran berlangsung, sehingga disiplin belajar peserta didik menjadi lemah dan tidak fokus dalam mengikuti pembelajaran.

Nilai koefisien korelasi yang diinterpretasikan secara kasar atau sederhana dengan mencocokkan hasil perhitungan dengan angka indeks korelasi " $r$ " product moment. Ternyata menunjukkan hasil besaran $r_{x y}(0,921)$ yang besarnya berkisar antara $0,81-$ 1,00 berarti korelasi antara penggunaan sosial media whatsapp memiliki pengaruh yang sangat kuat dengan disiplin belajar peserta didik pada mata pelajaran Pendidikan Agama Islam di SMK Analis Kimia YKPI Bogor pada tahun ajaran 2016/2017. 


\section{DAFTAR PUSTAKA}

Darwansyah, dkk. 2010. Pengantar Statistik Pendidikan. Jakarta: GP Press.

Hartanto, Aat. 2010. Panduan Aplikasi Smartphone. Gramedia Pustaka Utama: Jakarta.

Nasrullah, Rulli. 2015. Media Sosial. Sembiosa Rekatama Media: Bandung.

Rosenberg, Marc. J. 2001. ELearning: Strategies for Delivering Knowledge in the Digital Age. Mc Graw-Hill Company: USA.

Tambak, Syahrini. 2013. Pendidikan Komunikasi Islam. Kalam Mulia: Jakarta.

Sabri, Alisuf. 2008. Psikologi Pendidikan. Pedoman Ilmu Jaya: Jakarta.
Sukardi, 2008. Metodologi Penelitian Pendidikan Kompetensi dan Praktiknya. Bumi Aksara: Jakarta.

Sukmadinata, Nana Syaodih. 2009. Landasan Psikologi Proses Pendidikan. PT.Remaja RosdaKarya: Bandung.

Sugiyono, 2009. Metode Penelitian Kuantitatif Kualitatif dan $R$ \& D. Alfabeta: Bandung.

Syah, Muhibbin. 2008. Psikologi Belajar. Jakarta: PT. RajaGrafindo Persada: Jakarta.

Tu'u Tulus. 2004. Peran Displin pada Perilaku dan Prestasi Siswa. Jakarta: Grasindo.

Sumber Internet: http://www.whatsapp.com (diakses tanggal 20 April 2017 pukul 22.15. 
